\title{
Soil patterns and foliar standards for two cocoa clones in the States of Espírito Santo and Bahia, Brazil
}

\author{
Marcos Góes de Oliveira ${ }^{1}$ Fábio Luiz Partelli $^{1^{*}(\mathrm{D})}$ André Cayô Cavalcanti $^{1}$ \\ Ivoney Gontijo ${ }^{1}$ Henrique Duarte Vieira ${ }^{2}$
}

${ }^{1}$ Universidade Federal do Espírito Santo (UFES), Centro Universitário Norte do Espírito Santo (CEUNES), 29932-900, São Mateus, ES, Brasil. E-mail: partelli@yahoo.com.br. "Corresponding author.

${ }^{2}$ Universidade Estadual do Norte Fluminense Darcy Ribeiro (UENF), Campos dos Goytacazes, Rio de Janeiro, RJ, Brasil.

ABSTRACT: The objective of this research was to establish soil patterns and foliar standards for clonal crops of cocoa CCN51 and PS1319 in the Atlantic regions within the northern Espirito Santo and southern Bahia States. Samples were collected from September to October 2015, in 45 high productive plots, being 23 plots of clone CCN51 and 22 of clone PS1319. Sufficiency ranges for soil and foliar standards were recommended for cocoa clones CCN51 and PS1319 planted in the Northern Espirito Santo and Southern Bahia states. Differences in the contents of foliar macronutrients K, Ca, Mg, S and micronutrients Fe and Mn, were verified between clones CCN51 and PS1319. Differences reported for standards from different geographical regions confirmed that these standards need to be regional and specific for different cocoa clones.

Key words: Theobroma cacao L., mineral nutrition, sufficiency range, DRIS.

Padrões de solo e normas foliares para dois clones de cacau cultivados nos Estados do Espírito Santo e Bahia, Brasil

RESUMO: O objetivo deste trabalho foi estabelecer padrões de solo e padrões foliares para culturas clonais de cacau CCN51 e PS1319 nas regiões do Atlântico no norte do Espírito Santo e no sul da Bahia. As amostras foram coletadas de setembro a outubro de 2015 , em 45 parcelas de alta produtividade, sendo 23 parcelas do clone CCN51 e 22 do clone PS1319. As faixas de suficiência para solo e padrões foliares foram sugeridas para os clones de cacau CCN51 e PS1319 plantados no norte do Espírito Santo e no sul da Bahia. Diferenças nos teores dos macronutrientes foliares $\mathrm{K}, \mathrm{Ca}, \mathrm{Mg}$, S e micronutrientes Fe e Mn foram verificadas entre os clones CCN51 e PS1319. As diferenças relatadas para padrões de diferentes regiões geográficas permitem confirmar que esses padrões precisam ser regionais e especificos para diferentes clones de cacau.

Palavras chave: Theobroma cacao L., nutrição mineral, faixa de suficiência, DRIS.

\section{INTRODUCTION}

Cocoa (Theobroma cacao L.) belongs to the family Malvaceae, native from the hot and humid forests from the basins of the river Amazon and Orinoco (ARGOUT et al., 2001). Nowadays Brazil is the 6th largest cocoa producer, with a production of 190 thousand tons of dried beans in the 2016 harvest (FAOSTAT, 2016; ICCO, 2016).

Atlantic regions in the Espírito Santo and southern Bahia States have shown exceptional productivity and increase of planted areas, producing 208 thousand tons in the 2014/2015 harvest, corresponding to $82 \%$ of the national production (IBGE, 2015). In Brazil, cocoa is perfectly adapted to the edaphic and climatic conditions from these regions, significantly contributing to the regional development (CEPLAC, 2015).

A new period for the cocoa cropping has arisen in Brazil, characterized by full sun planting and the development of new clonal varieties exhibiting high productivity. Utilization of soil amendments and fertilizers in plantations with cocoa clones, in association to full sun cropping or adequate shading, has resulted in auspicious responses with productivity above $1.200 \mathrm{~kg} \mathrm{ha}^{-1}$, evidencing a close association between fertilization and productivity (CHEPOTE et al., 2013).

However, there is a lack of regional information regarding the demand of nutrients for these clonal varieties, a fact which may justify evaluations of the nutritional status of the plantations 
in the region. The absence of such information results in fertilization recommendations to be performed without any specific reference standard for the region. Nutritional monitoring of clonal varieties from foliar and soil fertility analysis, despite its simplicity, doesn't have any specific interpretation criteria for the northern Espírito Santo and southern Bahia States, thus depending on values published in literature for different edaphic and climatic conditions (CHEPOTE et al., 2013).

Foliar and soil fertility analysis have been frequently used in agriculture as an important tool for monitoring crops nutritional status. Interpretation and evaluation of the nutritional status has been performed specially by the method of sufficiency ranges (FS), due to the facility of interpretation of their results, once it considers a range of nutrient contents even in conditions of decreased growth and productivity (WADT et al., 2012; KURIHARA et al. 2013; SANTOS et al. 2013; PARTELLI et al., 2014; TEIXEIRA et al., 2015; XU et al., 2015).

Diagnosis and recommendation integrated system (DRIS) constitutes an alternative in these cases, once it allows obtaining nutritional standards from nutrient monitoring contents in the soil and leaves in commercial crops (BEAUFILS, 1973; JARREL \& BEVERLY, 1981; BALDOCK \& SCHULTE, 1996). Experimental methodology for the determination of DRIS reduces significantly costs and time needed to obtain these standards, and has encouraged research using the diagnosis and recommendation integrated system (WADT et al., 2012; DIAS et al., 2013; KURIHARA et al. 2013; SERRA et al. 2013; SOUZA et al., 2013; PARTELLI et al., 2014; QUEIROZ et al. 2014; SCUCUGLIA \& CRASTE, 2014; TEIXEIRA et al., 2015; XU et al., 2015).

DRIS is a method based in finding indices for each nutrient, which are calculated by functions which expresses the ratios of contents for each element regarding to the others (BEAUFILS, 1973; JARREL \& BEVERLY, 1981; BALDOCK \& SCHULTE, 1996), in addition, it allows to identify simultaneously imbalances, deficiencies and excess of nutrients in the soil and the vegetal tissue, classifying them in order of importance (WALWORTH \& SUMNER, 1986), thus enabling a more efficient nutritional diagnoses (PARTELLI et al., 2007; PARTELLI et al., 2016).

However, for the success of this method, the nutritional standard must be specific for each region (PARTELLI et al., 2007; WADT et al., 2012; DIAS et al., 2013), and may vary according to the plant genotype, age, phonological stage and the season of the year (PARTELLI et al., 2007; DIAS et al., 2013,
GOMES et al., 2016; DIAS et al., 2017; MATOS et al., 2017). DRIS standards were successfully used for various perennial crops, such as peach (AWASTHI et al, 2000), mango (RAJ \& RAO, 2006), cupuaçu (DIAS et al., 2011; WADT et al., 2012), guava (SOUZA et al., 2013), orange (DIAS et al., 2013; 2017), apple (XU et al., 2015) and grapes (TEIXEIRA et al., 2015). Yet, no DRIS standard was developed for cocoa.

Use of local nutritional standards (plant leaves and soil) may represent an alternative for the evaluation of crops and specific management systems. Therefore, obtaining regional standards and patterns may contribute to the rational use of inputs, improve the nutritional equilibrium of the plant and consequently, increase crop productivity. Thus, the objective of this research was to establish adequate soil standards and foliar patterns for the main cocoa clones used in the Atlantic regions of the northern Espírito Santo and southern Bahia States.

\section{MATERIALS AND METHODS}

The experiment was performed in commercial cacao crops located in the Atlantic regions from the northern Espírito Santo State, in the counties of Linhares, São Mateus, Aracruz and Sooretama and cocoa crops located in the southern Bahia State, in the counties of Eunápolis, Itabela and Mucuri. According to the Köppen's classification, the climate was determined as Aw, tropical with dry season in winter and rainy summer (KÖPPEN, 1931; ALVARES et al., 2013), in flat areas planted with cocoa.

From September to October 2015, 45 high productivie plantations (equal or higher than 1.500 $\mathrm{kg}$ ha-1 year-1) were monitored. Thus, 23 plantations of clone CCN51 and 22 plantations of clone PS1319 were evaluated, both clones cultivated at full sun with technologies available in the region.

For foliar sampling, approximately 150 leaves per plantation were collected, randomly distributing samplings from September to October, from approximately 15 plants distributed in each plantation. Leaves were collected at a medium height of the plant canopy, from new and recently matured branches. Contents of N, P, K, Ca, Mg, S, B, Cu, Fe, Mn and $\mathrm{Zn}$ were quantified from entire leaves, according CHEPOTE et al. (2013). Then, the test of Lilliefors was applied, establishing the value of $1 \%$, in order to verify the normality of the values corresponding to each nutrient, from the groups of high productivity plantations. This test is used to study estimated and calculated variances and has no restrictions for small samples (DALLAL \& WILKINSON, 1986). 
Soil and foliar samples were collected simultaneously, obtaining 12 simple samples per plantation. Soil samples were collected from a 0.00 $0.40 \mathrm{~cm}$ depth in an area under the projection of the canopy, in order to obtain a composite sample. A total of 45 composite soil samples were obtained, with 23 samples for the genotype CCN51 and 22 samples for the genotype PS1319, where the contents of organic matter, $\mathrm{Ca}, \mathrm{Mg}, \mathrm{K}, \mathrm{P}, \mathrm{S}, \mathrm{Zn}, \mathrm{B}, \mathrm{Cu}, \mathrm{Fe}$ and $\mathrm{Mn}$ were determined, in addition to the base saturation and cation exchange capacity at $\mathrm{pH} 7$, according to the methodology described by EMBRAPA (2013).

Research recommended that 20 plantations with nutrients displaying a normal distribution are sufficient to obtain DRIS standards (MOURÃO FILHO et al., 2002; REIS JÚNIOR \& MONNERAT, 2003; PARTELLI et al., 2006; PARTELLI et al., 2014). Therefore, plantations exhibiting contents of nutrients with normal distribution and high productivity were used to establish DRIS standards (mean of the relation between nutrients) and sufficiency ranges (mean, standard error and coefficient of variation of the nutrients content), with the same procedure applied for soil samples. All plantations under study were irrigated, had between 4 and 9 years old, were cultivated at full sun and were constantly fertilized according CHEPOTE et al. (2013).

To verify the difference between DRIS standards established for the different cocoa clones, the " $t$ " test of Student was used, once it has the capability to inform if there is a difference or not between the treatments' means (two clones) and to discriminate situations where the variance is homogeneous or heterogeneous (SAMPAIO, 2002). Statistical tests were performed at $1 \%$ and $5 \%$ significance.

\section{RESULTS AND DISCUSSION}

Statistical tests showed 20 monitored cocoa plantations of clone CCN51 and 20 plantations of clone PS1319 had normal distribution of nutrient contents, all being high productivity plantations with production of $1.500 \mathrm{~kg} \mathrm{ha}^{-1}$ year $^{-1}$; and therefore, qualifying to be used in the establishment of soil standard and foliar patterns, which may be used in the northern region of the Espírito Santo and Southern Bahia State.

DRIS standards for cocoa clones were obtained from nutritional relations. The coefficients of variation obtained for the relations between nutrients in leaves are under $50 \%$, except for the ratio $\mathrm{Ca} / \mathrm{Cu}$, observed in clone CCN51 (55.94\%), and for the ratio $\mathrm{Mn} / \mathrm{Mg}$ observed in clone PS1319 (51.47\%) (data not shown). Similar results were observed by SANTANA et al. (2008), while establishing DRIS standards in orange leaves. For those relationships, the high coefficients of variation observed for these relations demonstrated that reduced functions of these variables will have lower weight in the calculation of DRIS indexes.

From the 110 nutritional relations, 90 showed similarity $(\mathrm{p} \leq 0.05)$, signifying that only $18 \%$ of the nutritional indexes differ between the evaluated clones. Coefficients of variation obtained for the nutrients content in leaves are below 50\% (Table 1). According WALWORTH \& SUMNER

Table 1 - Sufficiency ranges, mean, standard error, coefficient of variation (CV) and "t" test of Student, for foliar contents of macronutrients $\left(\mathrm{g} \mathrm{kg}^{-1}\right)$ and micronutrients $\left(\mathrm{mg} \mathrm{kg}^{-1}\right)$ of high productivity cocoa genotypes, in Atlantic regions of the northern Espírito Santo and Southern Bahia States, Brazil.

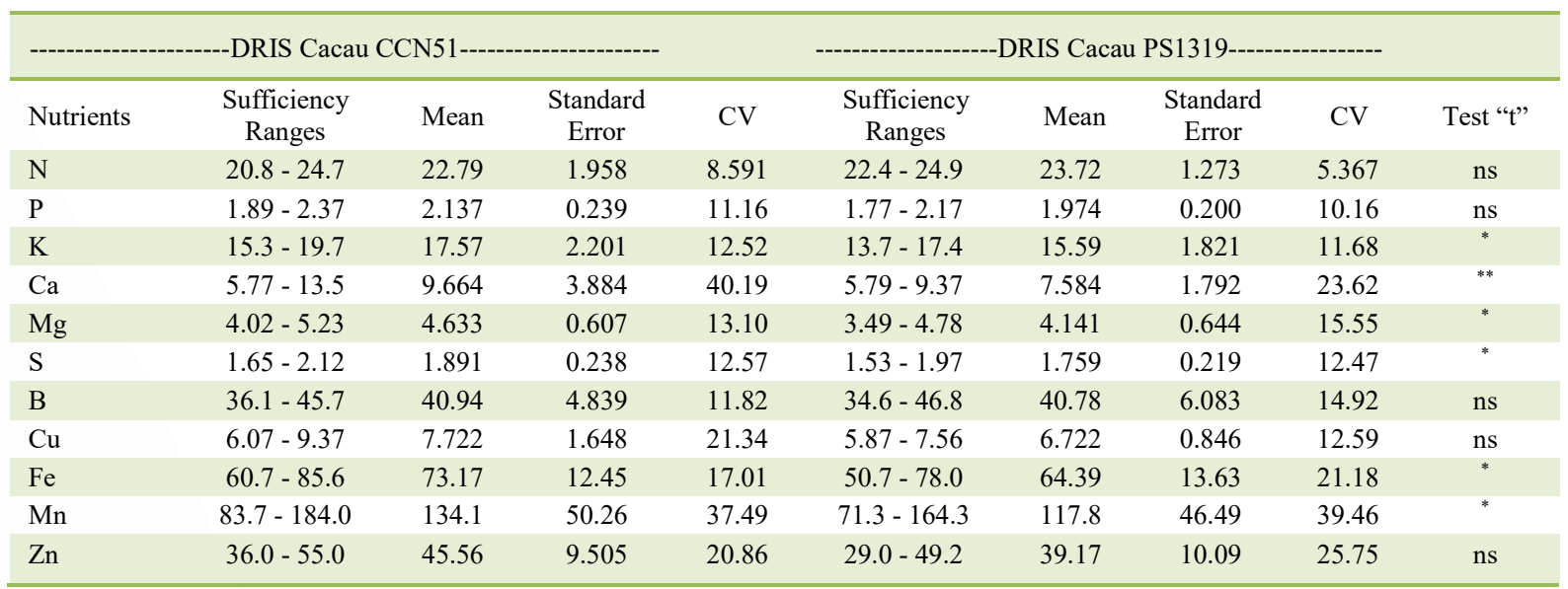

ns and ${ }^{* *},{ }^{*}$, represents not significant and significant at 1 and $5 \%$ probability, respectively. 
(1986), relations with coefficients of variation above $50 \%$ attribute lower weights to the calculus of DRIS indexes, due to the fact of the reduced functions being balanced by the respective coefficients of variation.

When comparing foliar contents of both clones evaluated (Table 1), significant differences among ranges of macronutrients $\mathrm{K}, \mathrm{Ca}, \mathrm{Mg}, \mathrm{S}$ and micronutrients Fe, Mn were verified. Therefore, these nutrients must be specific determined for different cacao clones. Once clones diverge and are highly influenced by their genetics and by the environment (ALMEIDA et al., 2009; ALEXANDRE et al., 2015).

Comparing values for foliar nutrients (Table 1) with using the sufficiency levels proposed in the manual for recommendations of liming and fertilization from Espírito Santo State (PREZOTTI et al.,2007) (Table 2), it is evident that $7,584 \mathrm{~g}$ $\mathrm{kg}^{-1}$ of Ca, 1,759 $\mathrm{g} \mathrm{kg}-1$ of $\mathrm{S}$ and $6,722 \mathrm{mg} \mathrm{kg}^{-1} \mathrm{of}$ $\mathrm{Cu}$ for genotype PS1319 and 7,722 $\mathrm{mg} \mathrm{kg}^{-1} \mathrm{Cu}$ for genotype CCN51, are below the recommended values. All other nutrients are adequate according the recommendations of the manual, as described by PREZOTTI et al. (2007). However, there are differences between the ranges (to CCN51and PS1319); and therefore, these must be regionalized according to the genotype. A fact that was also verified by DARA et al. (1992), REIS JÚNIOR \& MONNERAT (2003), PARTELLI et al. (2006), SANTANA et al. (2008) and WADT et al. (2012).

Calcium is a poorly mobile element in the phloem, thus deficiency symptoms occur in younger tissues such as leaves, growing organs or developing fruits in the first place. Elevated dosages of $\mathrm{Ca}$ and $\mathrm{S}$ may difficult absorption of $\mathrm{K}$ and $\mathrm{Mg}$, principally when the plant does not have a well-developed radicular system yet (CHEPOTE et al., 2013), a fact that stresses the importance of the nutritional equilibrium in the soil and plant. Copper is absorbed as $\mathrm{Cu}^{2+}$, elevated dosages of $\mathrm{Cu}$ may negatively influence the development of cocoa plants, significantly reducing the weight of roots (CHEPOTE et al., 2013).

Using the soil data from the same plantations to perform the foliar standards (20 for each clone) and perform the same statistical tests used for foliar samples, no statistical differences for soil variables were observed between both clones. Values of sufficiency ranges, means, standard errors, coefficient of variation (CV), were included in table 3 for soil where both clones are cultivated.

It is important that there are no soil fertility sufficiency ranges established for different clonal varieties in this region. Therefore, obtaining regional patterns may contribute to the rational use inputs with the improvement nutritional balance; and consequently, to increase productivity of cocoa plants.

Concern about micronutrients in crops has increased due to scientific advances resulting from research, which evidenced the important role of these nutrients. In cocoa, the required quantities of micronutrients are variable, mainly as a function of the plant age and the productivity expected. Knowledge on accumulation rates and the total accumulation in organs of this species and varieties has preponderant importance to assist the recommendation and adaptation of programs of crop fertilization, when working with optimal levels of productivity (CHEPOTE et al., 2013).

Table 2 - Foliar contents of macronutrients $\left(\mathrm{g} \mathrm{kg}^{-1}\right)$ and micronutrients $\left(\mathrm{mg} \mathrm{kg}^{-1}\right)$ considered adequate for coca according to the Manual for Recommending Liming and Fertilization in the Espírito Santo state, Brazil (PREZOTTI et al., 2007).

\begin{tabular}{|c|c|c|c|}
\hline \multirow[t]{2}{*}{ Nutrients } & --------.. & retation Cla & --------. \\
\hline & Low & Adequate & High \\
\hline $\mathrm{N}$ & $<20.0$ & $20.0-25.0$ & $>25.0$ \\
\hline $\mathrm{P}$ & $<1.80$ & $1.8-2.5$ & $>2.5$ \\
\hline K & $<13.0$ & $13.0-23.0$ & $>23.0$ \\
\hline $\mathrm{Ca}$ & $<8.0$ & $8.0-12.0$ & $>12.0$ \\
\hline $\mathrm{Mg}$ & $<3.0$ & $3.0-7.0$ & $>7.0$ \\
\hline $\mathrm{S}$ & $<1.60$ & $1.60-2.0$ & $>2.0$ \\
\hline B & $<25.0$ & $25.0-60.0$ & $>60.0$ \\
\hline $\mathrm{Cu}$ & $<8.0$ & $8.0-15.0$ & $>15.0$ \\
\hline $\mathrm{Fe}$ & $<60.0$ & $60.0-200$ & $>200$ \\
\hline $\mathrm{Mn}$ & $<50.0$ & $50.0-250$ & $>250$ \\
\hline $\mathrm{Zn}$ & $<30.0$ & $30.0-80.0$ & $>80.0$ \\
\hline
\end{tabular}


Table 3 - Mean, standard error, sufficiency range and coefficient of variation (CV) of soil chemical attributes planted with high productivity cocoa genotypes, in Atlantic regions of the Northern Espírito Santo and Southern Bahia states, Brazil.

\begin{tabular}{lcccc}
\hline Properties & Mean & Standard Error & Sufficiency Range & CV (\%) \\
\hline $\mathrm{MO}\left(\mathrm{dag} \mathrm{dm}^{-3}\right)$ & 2.28 & 0.20 & $2.0-2.6$ & 8.79 \\
$\mathrm{P}\left(\mathrm{mg} \mathrm{dm}^{-3}\right)$ & 28.6 & 8.39 & $14.0-53.0$ & 29.9 \\
$\mathrm{~K}\left(\mathrm{mg} \mathrm{dm}^{-3}\right)$ & 46.06 & 14.67 & $22.0-86.0$ & 31.9 \\
$\mathrm{Ca}\left(\mathrm{cmol}_{\mathrm{c}} \mathrm{dm}^{3}\right)$ & 2.39 & 0.80 & $1.2-3.9$ & 33.4 \\
$\mathrm{Mg}\left(\mathrm{cmol}_{\mathrm{c}} \mathrm{dm}^{3}\right)$ & 0.39 & 0.17 & $0.20-0.80$ & 43.2 \\
$\mathrm{~S}\left(\mathrm{mg} \mathrm{dm}^{-3}\right)$ & 12.06 & 3.98 & $8.0-20.0$ & 33.0 \\
$\mathrm{~B}\left(\mathrm{mg} \mathrm{dm}^{-3}\right)$ & 0.33 & 0.10 & $0.21-0.54$ & 30.0 \\
$\mathrm{Cu}\left(\mathrm{mg} \mathrm{dm}^{-3}\right)$ & 0.72 & 0.59 & $0.1-1.9$ & 82.3 \\
$\mathrm{Fe}\left(\mathrm{mg} \mathrm{dm}^{-3}\right)$ & 146.17 & 39.40 & $10.0-35.0$ & 30.0 \\
$\mathrm{Mn}\left(\mathrm{mg} \mathrm{dm}^{-3}\right)$ & 16.17 & 6.18 & $0.9-6.9$ & 38.2 \\
$\mathrm{Zn}\left(\mathrm{mg} \mathrm{dm}^{-3}\right)$ & 2.24 & 1.57 & $39.2-79.4$ & 49.9 \\
$\mathrm{Sat} . \mathrm{Bases}(\%)_{\mathrm{T}\left(\mathrm{cmol}_{\mathrm{c}} \mathrm{dm}^{3}\right)}^{54.88}$ & 11.38 & $3.68-6.31$ & 20.7 \\
\hline
\end{tabular}

It is important to emphasize that sampling, even when performed only in 20 plantations for each clone, was performed in fertilized, irrigated and full sun plantations. Soil patterns and foliar standards established in the present research may be used for nutritional and fertility diagnoses, respectively, for cocoa clones CCN51 and PS1319 planted in the northern Espírito Santo and Southern Bahia States, once studies concerning patterns and standards in these regions are practically nonexistent.

\section{CONCLUSION}

Soil patterns and foliar standards were recommended for cocoa crops planted with clones CCN51 and PS1319 in the northern Espírito Santo and Southern Bahia States. Differences occurred between foliar standards for macronutrients $\mathrm{K}, \mathrm{Ca}, \mathrm{Mg}, \mathrm{S}$ and micronutrients $\mathrm{Fe}$ and $\mathrm{Mn}$, among cocoa clones CCN51 and PS1319. Differences between foliar standards allow confirming that these standards must be regionally determined and specific for each genotype of cocoa.

\section{ACKNOWLEDGMENTS}

This study was funded by the Brazilian Federal Agency for Support and Evaluation of Graduate Education (CAPES - Finance code 001) and the Federal University of Espírito Santo.

\section{DECLARATION OF CONFLICT OF INTERESTS}

The authors declare no conflict of interest. The founding sponsors had no role in the design of the study; in the collection, analyses, or interpretation of data; in the writing of the manuscript, and in the decision to publish the results.

\section{AUTHORS' CONTRIBUTIONS}

All authors contributed equally for the conception and writing of the manuscript. All authors critically revised the manuscript and approved of the final version.

\section{REFERENCES}

ALEXANDRE, R.S., et al. Fruit characterization of cocoa clones in the coastal region of São Mateus city, ES. Revista Brasileira de Engenharia Agrícola e Ambiental. v.19, p.785-90, 2015. Available from: <https://doi10.1590/1807-1929/agriambi. v19n8p785-790>. Accessed: Mar. 16, 2018.

ALMEIDA, C.M.V.C., et al. Agronomical characterization of cacao accessions. Pesquisa Agropecuária Brasileira. v.44, p.368-73, 2009. Available from: <https://doi10.1590/S0100204X2009000400006>. Accessed: Mar. 15, 2018.

ALVARES, C.A., et al. Koppen's climate classification map for Brazil. Meteorologische Zeitschrift. v.22, p.11-28, 2013. Available from: <https://doi 10.1127/0941-2948/2013/0507>. Accessed: Mar. 19, 2018.

ARGOUT, X., et al. The genome of Theobroma cacao. Nature Genetics. v.43, p.101-9, 2001. Available from: $<$ https://doi10.1038/ ng.736>. Accessed: Mar. 17, 2018.

AWASTHI, R.P., et al. Diagnosis and Recommendation Integrated System (DRIS) norms for peach (Prunus persica L.) CV July Elberta in Himachal Pradesh. Indian Journal Horticulture. v.57, p.27780, 2000. Available from: <https://www.cabdirect.org/cabdirect/ abstract/20013098141>. Accessed: Mar. 02, 2018.

BALDOCK, J.O.; SCHULTE, E.E. Plant analysis with standardized scores combines DRIS and sufficiency range approaches for

Ciência Rural, v.49, n.10, 2019. 
corn. Agronomy Journal. v.88, p.448-56, 1996. Available from: $<$ https://doi: 10.1007/BF00011708>. Accessed: Nov. 18, 2017.

BEAUFILS, E.R. Diagnosis and Recommendation Integrated System (DRIS); a general scheme for experimentation and calibration based on principles develop from research in plant nutrition. Soil Science Bulletin v.1, p.1-132, 1973. Available from: <http://dx.doi.org/10.1590/S0102-05362014000200014>. Accessed: May,16, 2019.

COMISSÃO EXECUTIVA DO PLANO DA LAVOURA CACAUEIRA - CEPLAC - Lista de clones. 2015 [Accessed 10 of August 2016]. Available from: $<$ http://www.ceplac.gov.br/radar/ ListaClones. asp>. Accessed: Oct. 10, 2016.

CHEPOTE, R.E, et al. Recomendações de corretivos e fertilizantes na cultura do cacaueiro no Sul da Bahia $-3^{\mathrm{a}}$ aproximação. Ilhéus: CEPLAC/CEPEC; 2013. Available from: $<$ http://www.ceplac.gov.br/agrotropica/avulsos/recomendacoes. pdf>. Accessed: Oct. 16, 2017.

DALLAL, G.E.; WILKINSON, L. An analytic approximation to the distribution of 'Lilliefors' test for normality. The American Statistical. v.40, p.294-6, 1986. Available from: <https:// doi 10.1080/00031305.1986.10475419>. Accessed: May.16, 2018.

DARA, S.T., et al. Sufficiency level and Diagnosis and Recommendation Integrated System approaches for evaluating the nitrogem status of the corn. Agronomy Journal. v.84, p.1006-10, 1992. Available from: <https://doi 10.2134/agronj1992.000219620 08400060020x>. Accessed: Mar. 16, 2018.

DIAS, J.R.M, et al. Anticipation of the period for foliar diagnosis in 'Pêra' orange tree in Amazon state, Brazil. Pesquisa Agropecuária Brasileira. 48, p.757-64, 2013. Available from: $<$ https://doi10.1590/S0100-204X2013000700008>. Accessed: Oct. 16, 2017.

DIAS, J.R.M., et al. Normal nutrient ranges and nutritional monitoring of 'Pêra' Orange trees based on the CND method in different fruiting stages. Pesquisa Agropecuária Brasileira. v.52, p.776-785, 2017. Available from: <https://doi10.1590/S0100204X2017000900010>. Accessed: Mar. 03, 2018.

DIAS, J.R.M., et al. Dris formulas for evaluation of nutritional status of cupuaçu trees. Revista Brasileira de Ciência do Solo. v.35, p.2083-91,2011. Available from: <https://doi10.1590/S010006832011000600023>. Accessed: Mar. 18, 2018.

EMBRAPA - EMPRESA BRASILEIRA DE PESQUISA AGROPECUÁRIA. Sistema brasileiro de classificação de solos. 3a ed. Rio de Janeiro: Embrapa Solos; 2013. Available from: $<$ http://www.agrolink.com.br/downloads/sistema-brasileiro-declassificacao-dos-solos2006.pdf>. Accessed: May. 18, 2017.

FAOSTAT. Food and Agricultural Organization of the United Nation Statistics Data Retrieved, July 16, 2016. Available from: $<$ http://www.fao.org/statistics/en/>. Acessed: May, 18, 2016.

GOMES, W.R., et al. Genetic diversity of standard leaf nutrients in Coffea canephora genotypes during phenological phases. Genetics and Molecular Research. 15:gmr.15048839, 2016. Available from: $<$ http://dx.doi.org/10.4238/gmr.15048839>. Accessed: Mar. 18, 2018.

IBGE - Instituto Brasileiro de Geografia e Estatística. Produção agrícola estadual: lavoura temporária. 2015. Available from:
$<$ http://www.ibge.gov.br/estadosat/temas.php?sigla=go\&tema=lav ouratemporaria2011>. Accessed May,17, 2017.

ICCO. International Cocoa Organization. Produção mundial de cacau. 2016. Available from: <http://www.icco.org/>. Accessed: Mar. 16, 2018.

JARREL, W.M.; BEVERLY, R.B. The dilution effect in plant nutrition studies. Advances in Agronomy. v.34, p.197-224, 1981. Available from: <https://doi10.1016/S0065-2113(08)60887-1>. Accessed: Mar. 16, 2018.

KÖPPEN, W. Climatologia. México: Fundo de Cultura Econômica; 1931.

KURIHARA, C.H., et al. Sufficiency range for nutrient concentration in cotton and soybean leaves, defined through DRIS indexes. Ceres. v.60, p.412-9, 2013. Available from: $<$ https://doi10.1590/S0034-737X2013000300015>. Accessed: Mar. 16, 2018.

MATOS, G.S.B., et al. The Use of DRIS for Nutritional Diagnosis in Oil Palm in the State of Pará. Revista Brasileira de Ciência do Solo. 41:e0150466, 2017. Available from: <https://doi10.1590/180 69657rbcs20150466>. Accessed: Mar. 16, 2018.

MOURÃO FILHO, F.A.A., et al. Functions and ratio order of the nutrients at the establishment of DRIS norms in 'Valencia' sweet orange. Pesquisa Agropecuária Brasileira. v.37, p.185-92, 2002. Available from: <https://Doi10.1590/S0100204X2002000200010>. Accessed: Mar. 16, 2018.

PARTELLI, F.L., et al. Nutritional Assessment Of The Irrigated Common Bean Crop By The CND, DRIS, and Sufficiency Range Methods. Revista Brasileira de Ciência do Solo. 38:858-66, 2014. Available from: <https://doi10.1590/S010006832014000300017>. Accessed: Mar. 16, 2018.

PARTELLI, F.L., et al. Leaf Norms And Nutrition Diagnosis Of Coffee Conilon in Floweting And Graining In Espírito Santo. Coffee Science. v.11, p.544-54, 2016. Available from: <http:// www.coffeescience.ufla.br/index.php/Coffeescience/article/ view/1177>. Accessed: Oct. 12, 2017.

PARTELLI, F.L., et al. Diagnosis and recommendation integrated system norms, sufficiency range, and nutritional evaluation of Arabian coffee in two sampling periods. Jounal of Plant Nutrition. v.30, p.1651-67, 2007. Available from: <https:// doi10.1080/01904160701615525>. Accessed: Oct. 01, 2017.

PARTELLI, F.L., et al. Nutritional diagnosis of the organic Conilon coffee trees (Coffea canephora Pierre ex Froehn): suffiency range approach for leaves and soil. Coffee Science. v.1, p.43-9, 2006. Available from: <http://www.coffeescience. ufla.br/index.php/Coffeescience/article/viewFile/18/75>. Accessed: Oct. 01, 2017.

PREZOTTI, L.C., et al. Manual de recomendação de calagem e adubação para o estado do EspíritoSanto. $5^{\text {a }}$ aproximação. Vitória, ES: SEEA/INCAPER/CEDAGRO. 2007. Available from: <https:// biblioteca.incaper.es.gov.br/digital/bitstream/123456789/3242/1/ manualderecomendacaodecalagemeadubacao.pdf $>$. Accessed: Oct. 01, 2017.

QUEIROZ, A.A., et al. Productivity and establishment of DRIS indices for tubers of the potato cultivar 'Agata'. Revista 
Ciência Agronômica. v.45, p.351-60, 2014. Available from: $<$ https://doi10.1590/S1806-66902014000200017>. Accessed: Mar. 16, 2018.

RAJ, G.B.; RAO, A.P. Identification of yield-limiting nutrients in mango through DRIS indices. Soil Science Plant Nutrition. v.37, p.1761-74, 2006. Available from: <https:// doi10.1080/00103620600710587>. Accessed: Oct. 11, 2017.

REIS JÚNIOR, R.A.; MONNERAT, P.H. Norms establishment of the Diagnosis and Recommendation Integrated System (DRIS) for nutritional diagnosis of sugarcane. Pesquisa Agropecuária Brasileira. v.38, p.277-82, 2003. Available from: $<$ https://doi10.1590/ S0100-204X2003000200015>. Accessed: Oct. 17, 2017.

SAMPAIO, I.B.M. Estatística Aplicada à Experimentação Animal. Belo Horizonte: FEP-MVZ; 2002.

SANTOS, E.F., et al. Normal Nutrient Ranges for sugarcane by the methods ChM, DRIS and CND and critical level by Reduced Normal Distribution. Revista Brasileira de Ciência do Solo. 37:1651-8, 2013. Available from: <https://doi10.1590/S010006832013000600021>. Accessed: Oct. 17, 2017.

SANTANA, J., et al., Dris Norms Interpretation For Plant Tissue And Soil For "Pera" Range In The Goias State Central Region. Pesquisa Agropecuária Tropical, v.38, p.109-117, 2008. Available from: $<$ https://doi 10.5216/pat.v38i2.4160>. Accessed: Oct. 18, 2018.

SCUCUGLIA, C.L.; CRESTE, J.E. Diagnosis and recommendation integrated system (DRIS) of tomato in greenhouse. Horticultura Brasileira. v.32, p.200-
204, 2014. Available from: <https://doi10.1590/S010205362014000200014>. Accessed: Oct. 17, 2017.

SERRA, A.P., et al. Establishing DRIS norms for cotton with different selection criteria for the reference population. Pesquisa Agropecuária Brasileira. v.48, p.1472-80, 2013. Available from: $<$ https://doi10.1590/S0100-204X2013001100008>. Accessed: Oct. 17, 2017.

SOUZA, H.A, et al. Preliminary Dris Norms And Sufficiency Range For 'Paluma' Guava Tree. Revista Brasileira de Fruticultura. v.35, p.282-91, 2013. Available from: <https://doi10.1590/ S010029452013000100033>. Accessed: Oct. 17, 2017.

TEIXEIRA, L.A.J, et al., Dris Norms And Critical Leaf Nutrient Levels For 'Niagara Rosada' Grape In Jundiaí Region, São Paulo (Brasil). Revista Brasileira de Fruticultura. v.37: p.247-55, 2015. Available from: <https://doi:10.1590/0100-2945-409/13>. Accessed: Oct. 17, 2017.

WADT, P.G.S, et al. Interpretação de Índices Dris para a cultura do cupuaçu. Revista Brasileira de Ciência do Solo. v.36, p.125-35, 2012. Available from: <https://doi:10.1590/ S010006832012000100014>. Accessed: Sep. 17, 2017.

WALWORTH, J.L.; SUMNER, M.E. Foliar diagnosis: A review. Advanced Plant Nutrition. v.3, p.193-241, 1986.

XU, M., et al. Nutritional Diagnosis for Apple by DRIS, CND and DOP. Advance Journal of Food Science and Technology. v.7, p.266-73, 2015. Available from: <https://doi:10.1590/S010390162004000500008>. Accessed: Sep. 25, 2017. 